\title{
高中政治学科核心素养培养探究
}

谢成松

重庆市涪陵第十七中学校

DOI:10.32629/er.v2i10.2132

[摘 要] 政治教学的核心素养培养可以体现在很多方面。教师既要充分从知识要点出发, 也要善于引发各种生活中的典型实例, 还可以调动学 生自身的生活经验。教师要加强对学生思维能力的培养与锻炼, 结合教学内容有效融入情感教育, 让学生具备更好的实践能力, 本文对此进行了 分析研究。

[关键词] 高中; 政治核心素养; 培养

\section{1 核心素养的概念及其意义}

中国学生所需要发展的核心素养, 主要是指“学生应具备的, 能够适应 终身发展和社会发展需要的必备品格和关键能力。” 培养学生的核心素养 是顺应新课程教育改革的素质教育理念, 满足社会发展进步的人才需求的 重要举措。它以培育学生的个人综合素养为核心, 对学生在整个人生进程 中的发展以及成才都有着巨大的助益。它适应了当今世界范围内的教育改 革发展趋势, 并能够有效提升我国教育的国际竞争。

\section{2 高中政治的核心素养的培养策略}

2.1开展以学生为中心的多元活动

就学生构建核心素养的能力而言, 仅凭讲解远远不够。要让学生养成 道德核心素养, 离不开课堂的教学内容。教师需要从课堂教学出发, 结合教 材内容, 细化每一个知识点, 从而制定相对应的教学目标。也就是说, 只有 先制定出相关核心素养的目标, 才能引导出接下来的学习重难点和学习计 划, 最终达成学习目标的实现, 并且间接地促使学生养成良好的核心素养。 与此同时, 挖掘生活中的素材和时事政治事件加入课堂教学。开展多种多 样的活动, 如组织学生进行社会问题调查研究, 设立相关课题, 写小论文, 组织社会热点问题辩论等, 加强学生的参与度, 提高学生学习热情。

2. 2 结合教学内容有效融入情感教育

很多学生之所以对于政治课程的学习兴趣不高, 一个重要原因在于大 家觉得这门课程理论性过强, 且很多知识点难以理解, 有较大的学习障碍。 了解到这种基本情况后, 教师要在教学方法和教学组织形式上有所调整与 转变, 要转化教学策略, 化解学生的知识理解障碍。一个很有效的方法就是 从知识内容的教学出发融入情感教育。通过对学生内在积极情感的引发, 不仅会让学生对知识及问题的探讨更加主动与投入, 思考探究的效果也会 更加理想。在这种积极学习的背景下不更有助于对学生学科能力的锻炼和 核心素养的培养, 也会让学生慢慢感受到这门课程学习探究的内在趣味。

2. 3 辨析式学习过程的价值引领

教学中要精选范例, 通过实例分析, 提炼观点。在矛盾冲突中进行甄 别、理解、深化、总结。如在法制教育课程中, 可以选择身边的案例进行 分析, 成立模拟法庭, 由学生扮演律师进行辩护和旁听, 使学生身临其境的 用所学知识进行实战演习, 从而加深课本知识的认识和理解。此外, 还可以 通过探究活动来拓展视野和能力。对一些社会性问题, 如噪音污染、光污 染等进行问卷调查、结果分析、查阅文献, 分析其形成原因和本质, 并提出 解决方法。

\section{4设计综合性的教学形式}

政治理论虽然抽象但却与生活密切相关, 而教学形式的多样化则有助 于学生理解政治学科的素养。如今教育改革的方向, 是要学生将在课堂中 学习到的知识重新運用到生活中去。因此, 在课堂教学中, 教师就应该带入
一些社会时事热点内容, 拉近学生与社会之间的距离。在进行一堂课之前, 教师可以根据教学内容, 播放一些相关的广告或其它影音内容, 然后进行 提问, 让学生进行思考和讨论, 再将得出的结论引入到课堂知识点中。如在 讲授保护消费者权益相关内容的时候, 可以通过播放 315 节目的一些短片, 让学生分组, 一组扮演销售者, 一组扮演消费者, 一组扮演生产商, 进行辩 论, 到底谁是受害者, 谁是责任方, 结合实际培养学生的理性精神。这样就 在很好的结合社会热点的同时, 让学生更加深入的感受到书本与社会之间 的关系。

2. 5 广泛开展系列化社会活动

政治来源于生活, 更要学以致用地去应用于生活。因此, 培养学科素养 参加社会化活动是必不可少的环节。学校要多通过开展校外的综合实践活 动, 让学生感受政治学科的用处, 培养公共意识和社会责任, 积极履行公民 的责任和义务。

2. 6 构建合理的评价体系

在以往的高中政治教学进程中, 对于学生最终学习情况的考核主要都 是通过考试成绩来进行的。这种考核方式就促使学生只重视对于政治学习 成绩的提升, 并且认为死记硬背就能达到应有的效果, 完全忽视了对于个人 综合能力的自我发展和培养。为了在一定程度上对于这种情况进行改善, 高 中政治教师需要对学生的学习评价体系进行创新。一方面教师需要关注学 生的学业情况, 而另一方面教师更需要重视对于学生核心素养的培育成果。

对于学生核心素养培育成果的评估将会从多个角度来进行, 并且囊括 着学生课堂课后表现的方方面面。例如学生在课堂中进行举手发言的频次 和质量, 学生在相关的主题教学活动中的参与程度和表现情况, 学生在课 外参与时政热点相关的实践活动的情况等等。高中政治教师转变评价体系, 也就直接促进了学生自我观念的转化, 提升了学生自主培养自身的核心素 养的相关意识。

\section{3 结语}

高中思想政治教育对于学生的发展具有积极的作用, 教师要加强对此 的重视程度, 注重在教学方式、内容上进行相应的创新, 进而培养学生的政 治素养。同时, 在教学过程中, 也要注重联系实际, 让学生可以更好的将一 些理论性的知识点应用到社会中。

\section{[参考文献]}

[1]张芳.高中生思想政治学科核心素养的培育研究 [D]. 四川师范大 学,2017(02):73.

[2]孟庆英.浅谈高中政治学科培养学生核心素养的路径[J].中国校外 教育,2018(33):15.

[3]张锋.论高中政治学科培养学生核心素养的路径 [J]. 华夏教 师,2019(12):96. 